ppi $201502 Z U 4645$

Esta publicación científica en formato digital es continuidad de la revista impresa ISSN-Versión Impresa 0798-1406 / ISSN-Versión on line 2542-3185Depósito legal pp $197402 Z$ U34
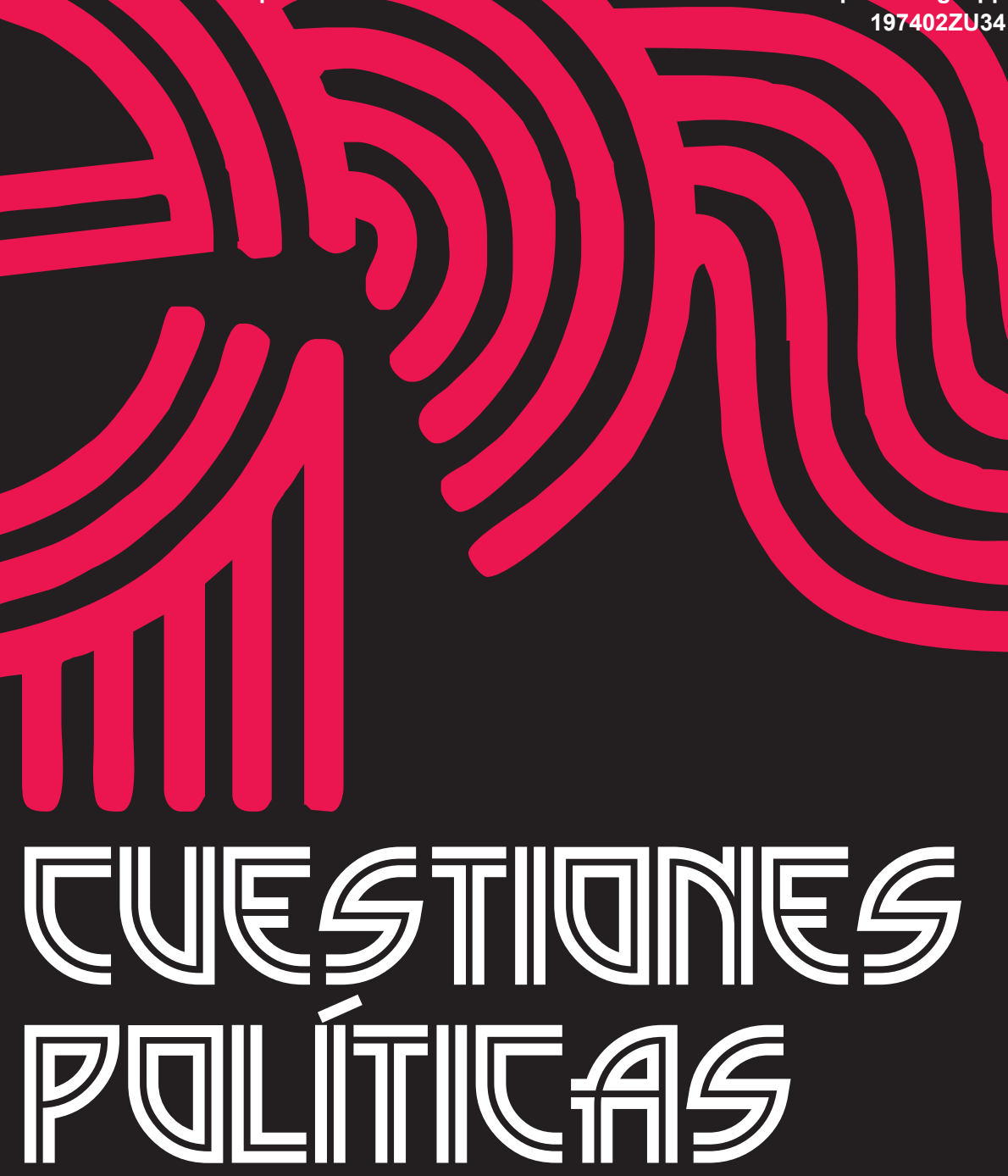

Instituto de Estudios Políticos y Derecho Público "Dr. Humberto J. La Roche" de la Facultad de Ciencias Jurídicas y Políticas de la Universidad del Zulia Maracaibo, Venezuela
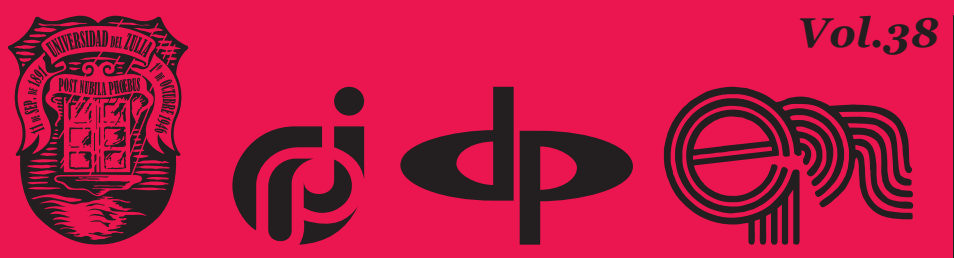

$N^{\circ}$ Especial 2da Parte 2020 


\title{
Training and implementation of the environmental, economic, and legal development policy of the regions: main practice-oriented approaches
}

\author{
DOI: https://doi.org/10.46398/cuestpol.382e.15
}

\author{
Hryhorii Bukanov * \\ Svitlana Skakouska ** \\ Viktor Kulbaka *** \\ Olena Sytnichenko **** \\ Olesia Kulbaka *****
}

\section{Abstract}

The article explores the possibilities of practice-oriented approaches in public administration, in the field of training and implementation of the ecological development policy of the regions, between areas, modern social and economic conditions instead. The methodological basis of the study consists of general scientific methods of cognition and social processes (analysis, synthesis, generalization, classification) and sociological methods for obtaining empirical data. The forms of optimization of public administration in the field of training and implementation of the ecological development policy of the regions are concluded, manifested in the practice-oriented approaches select in the following directions: from the framework outside responsibility and legal in the field of environmental protection; strengthening the role of economic mechanisms and environmental management tools in the regions; modernization of the public and state administration system in the field of environmental protection, and; Dissemination of an instrument of cross-

* Department of Management and Project Management, Dnipropetrovsk Regional Institute of Public Administration of the National Academy of Public Administration under the President of Ukraine, Dnipro. ORCID ID: http://orcid.org/oooo-0oo2-5398-5953. Email: andreyl@gmail.com

** Senior Lecturer, Department of Finance and Environmental Economics "National University of Water and Environmental Engineering”, Rivne, Ukraine. ORCID ID: orcid.org/oooo-0002-3415-9613. Email: fotissvit@gmail.com

*** Department of Economic Theory and Law, Prydniprovska State Academy of Civil Engineering and Architecture Ukraine. ORCID ID: https://orcid.org/oooo-ooo3-3634-4334. Email: kafuniv@ukr.net

**** Department of Legal Support business security of Kyiv National University of Trade and Economics, Kiev, Ukraine. ORCID ID: https://orcid.org/oooo-0002-9740-0216. Email: sitnichenko@ukr.net

*****Department of Roads, Geodesy and Land, Prydniprovska State Academy of Civil Engineering and Architecture Ukraine. ORCID ID: https://orcid.org/oooo-0oo2-6066-8112. Email: kafuniv@ukr.net 
sectoral social collaboration in the field of training and implementation of ecological development policy.

Key words: environmental management; public administration in Ukraine; cluster approach; management of environmental projects; regional development.

\section{Formación e implementación de la política de desarrollo ambiental, económico y legal de las regiones: principales enfoques orientados a la práctica}

\section{Resumen}

El artículo estudia las posibilidades de los enfoques orientados a la práctica en la administración pública, en el campo de la formación e implementación de la política de desarrollo ecológico de las regiones, entre las cuales destacan, las condiciones sociales y económicas modernas de Ucrania. La base metodológica del estudio se compone de métodos científicos generales de cognición de fenómenos y procesos sociales (análisis, síntesis, generalización, clasificación) y métodos sociológicos para la obtención de datos empíricos (estudio sociológico experto). Se concluye que las formas de optimización de la administración pública en el campo de la formación e implementación de la política de desarrollo ecológico de las regiones, se manifiestan en los enfoques orientados a la práctica seleccionados en las siguientes direcciones: mejora del marco regulatorio y legal en el campo de la protección ambiental; fortalecimiento del rol de los mecanismos económicos y herramientas de gestión ambiental en las regiones; modernización del sistema de administración pública y estatal en el campo de la protección ambiental, y; Difusión de un instrumento de colaboración social intersectorial en el campo de la formación e implementación de la política de desarrollo ecológico.

Palabras clave: gestión ambiental; administración pública en Ucrania; enfoque cluster; gestión de proyectos ambientales; desarrollo regional.

\section{Introduction}

Sustainable (balanced) development of the regions presupposes the development of all its components, in particular the ecological one. In a 
broad sense, the greening of state and regional development is a natural process of further improving economic relations and the achieved level of development of productive forces, based on an environmentally oriented innovation policy of the state and regions to ensure the environmental safety of the state and its territories. The ecological development of the region is carried out through the mechanisms of public administration, which ensures the effective functioning of the entire system of public and local authorities and provides for the wide involvement of various stakeholders in the development and implementation of state policy (Pollitt and Bouckaert, 2004) is implemented through the formation and implementation both the strategy of state (national) policy and regional environmental policy.

\section{Materials and methods}

It is unconditional that an important component of the state environmental policy is the regional environmental policy of the country, which will contribute to the solution of regional environmental problems, on which the social and economic stability of the country as a whole largely depends.

The regional environmental policy of the country is one of the indispensable conditions for maintaining security, ensuring social and economic and geopolitical stability, and implementing the regional development model. As noted by M. Andriienko and V. Shako, the regional environmental policy of the country is an organic component of the national environmental policy, and in the context of decentralization of management, environmental protection management, rational use of natural resources and the safety of life of people at the regional level are of particular relevance, carried out with the help of mechanisms, aimed at stimulating the development of the regions, relying mainly on regulatory environmental national and international legislation, standards and norms (Andriienko and Shako, 2017).

So, the ecological system of the region is basic for ensuring the sustainable development of other systems - economic and social, so the regional level requires the creation of a fundamentally new system of territorial management in the field of environmental protection (Koval and Mikhno, 2019). This gives rise to the objective need for regional differentiation of management decisions and practical actions aimed at stabilizing and improving the environmental situation, and therefore the need for the formation and implementation of regional environmental policy is actualized. And the main approaches to the formation of the policy of environmental development of the regions and the regional environmental policy itself are cluster, program-target, project-oriented and managementoriented approaches in the practice of state and public administration. 
Thus, the purpose of the article is to highlight modern and effective and practice-oriented approaches and their potential in managing the ecological development of the regions. Achievement of this goal presupposes the solution of the following tasks: 1 ) identification and analysis of the main practice-oriented approaches in managing the ecological development of the regions; 2) identification of potential opportunities for the implementation of mechanisms and tools of the selected approaches in environmental protection management at the regional level (based on the results of empirical research); 3) highlighting the trends and ways of public administration in the field of environmental development of the regions.

The methodological basis of the study is made up of general scientific methods of cognition of social phenomena and processes (analysis, synthesis, generalization, classification) and sociological methods for obtaining empirical data (expert sociological survey). The empirical basis of the study is the results of an expert survey of environmental management entities - the representatives of regional government bodies, public organizations, business structures, scientific ecological community of Zaporizhzhia region (January, 2020: 200).

The practical significance of the results of theoretical and empirical analysis lies in determining the most effective practice-oriented approaches in managing the ecological development of the regions to create conditions for the formation and implementation of regional environmental policy in the form of specific targeted environmental programs, environmental projects, organizational management structure and the creation and development of environmental clusters in the spatial limits of the region.

The main markers for identifying civic identity were such linguistic constructs that reveal the presence of: aggressive rhetoric against representatives of another identification group; rhetoric of classifying a subject as a member of a particular youth group (online or offline); the rhetoric of describing their objective socio-political reality; rhetoric of assessing the negativism and hopelessness of the future of modern youth; political protest rhetoric; rhetoric of social and political activism.

\section{Results and discussion: Practice-Oriented approaches in the management of ecological development of the regions}

Among the many approaches in state and public administration, we have identified program-target, cluster, project-oriented and managementoriented approaches, which, in our opinion, are most effective in the formation and implementation of the policy of ecological development of the regions in modern social and economic conditions. Therefore, let us consider their potential in environmental management at the regional level. 
Hryhorii Bukanov, Svitlana Skakovska, Viktor Kulbaka, Olena Sytnichenko y Olesia Kulbaka Training and implementation of the environmental, economic, and legal development policy of 204 the regions: main practice-oriented approaches

The program-targeted approach is a way of forming a system of planned solutions to significant national and regional problems, the essence of which is to determine the main goals of social, economic and environmental development, to develop interrelated measures to achieve them within the specified time frame with balanced resource provision. The use of the program-targeted approach allows for a comprehensive solution of environmental protection problems in the territory of a particular region, including: 1) alignment the goals and objectives of the environmental program with the goals and objectives of other long-term target programs of the region; 2) taking into account the scale, complexity and diversity of problems of ecological development of the region; 3) combination of administrative and control and economic management tools in the field of environmental protection; 4) consistent integration of environmental goals into the process of sustainable (balanced) development of the region; 5) coordination of setting and achieving balanced current and long-term environmental goals; 6) formation of favorable conditions for "green" investments in the economic space of the region (Pakulina et al., 2019; Yankovyi et al., 2020).

Thus, the implementation of the program-targeted approach in managing the environmental development of the region provides for the development regional environmental programs that may be part of the general strategic program for the social and economic development of the region.

So, at the regional level, it is the program-targeted approach in the formation of environmental policy that is most acceptable in the modern conditions of social and economic development in Ukraine and the reform of the public administration system through the processes of decentralization and regionalization of the powers of government bodies in various spheres, in particular in the field of environmental protection. An urgent issue in this sense today is the definition of the spatial boundaries of the region to improve the efficiency of management in the implementation of regional environmental policy, which is currently being carried out on the basis of the administrative-territorial division of the regions - areas.

The system of budgetary financing of programs for the social and ecological and economic development of the regions and the assessment of the results of the implementation of the developed environmental programs for the development of territories are built on this principle. Among the promising approaches to the formation of the spatial boundaries of the implementation of regional environmental policy, the cluster approach stands out, the application of which is defined as a global trend in the implementation of sustainable (balanced) development goals at all levels international, national, regional, local. 
The approach to the formation of a model of environmental policy of the regions based on the creation of environmental clusters has not yet become widespread in Ukraine, but it should be noted that its essence lies primarily in the unification and integration of efforts of state authorities, economic entities, scientific centers and the public in achieving goals sustainable development of the region. In this sense, the cluster is a set of related industries serving medium and small businesses, scientific and educational institutions that form human and innovative potential, sufficient human resources, the synergistic effect of interaction of which is in high indicators of the social and economic and environmental development of the region. The most effective level of development of territories can arise in integrated ecological and economic systems - environmentally oriented clusters, by which Dehtiarova, understands: "Economic complexes in which individual economic entities are linked into single cycles in such a way that the processes of economic activity are mutually processes of reproduction of ecosystem components"(2010: 123).

To a large extent, the creation and development of regional clusters will be facilitated by its institutionalization at the level of state and public administration in the region, what turns out to be in the formation of the system of institutional features of the social and ecological and economic cluster. Thus, Tomareva-Patlakhova (2017) notes that the institutional component of the regional cluster model is becoming an integral system of sustainable development, which should provide for the improvement of legal regulation and organizational and economic support for the optimization of the social, economic and environmental components of the region at the level of application of the program-targeted method of reform economy of the region (Tomareva-Patlakhova, 2017; Tamosiuniene et al., 2019).

Thus, the creation of an environmental cluster presupposes: firstly, the definition of spatial boundaries, production potential, service infrastructure and human potential; secondly, the involvement of the main actors of the ecological cluster - government entities, local administrations, economic entities, public, research and educational centers and institutions; thirdly, the creation of an organizational and management system of the cluster and the definition of its functional tasks; fourthly, the formation and implementation of the environmental policy of the cluster; fifthly, the allocation and implementation of tools for managing the social and economic and environmental development of the cluster; sixthly, the development of a system of criteria for assessing the effectiveness and efficiency of the functioning of the cluster in the context of sustainable (balanced) development (social, economic and environmental components).

Thus, the use of the cluster approach in the formation of the policy of ecological development of the region presupposes: firstly, the selection 
Hryhorii Bukanov, Svitlana Skakovska, Viktor Kulbaka, Olena Sytnichenko y Olesia Kulbaka Training and implementation of the environmental, economic, and legal development policy of 206 the regions: main practice-oriented approaches

and creation of an ecological and economic cluster and the definition of its spatial boundaries; secondly, institutionalizing the development of environmental innovation policy in the region; thirdly, the creation and strengthening of relationships between various subjects of the cluster: state, economic, social and public.

The project-oriented approach in the formation and implementation of the regional environmental development policy provides for the use of project management tools, benchmarking in the field of environmental protection and environmental marketing in the context of sustainable (balanced) development of territories. Today, it is relevant to use project management technologies in the process of implementing the strategic program for the environmental development of the region and clusters, in particular Kozachenko (2018) interprets project management as: "A field of activity in the process of which the project's goals are determined and achieved while balancing between the volume of works, resources, quality and risks".

And project management in the public sphere is a process of institutionalizing, into a programmed-target format, the methods of intervention of authorities or local governments in social reality in order to solve a public problem. At the same time, under conditions of limited time and resources, unique products or services are created that have not been developed before and differ from existing analogues (Chemerys, 2012). Thus, project administration or project management in the field of environmental development of a region can be defined as a process of institutionalization in the program-target format of methods of intervention of authorities or local governments in the field of formation and implementation of regional environmental policy to achieve the goals of sustainable (balanced) development of the region and the state in general (Popova et al., 2020).

In the context of the ecological development of the regions, project management as a direction of management in the field of implementation of regional environmental policy will contribute to: 1 ) institutionalization of the program-targeted management of regional environmental policy; 2) formation of a unified regional information according the problems of environmental safety of the region and organizations (institutions, enterprises, associations, etc.) that have the resources (material and financial, technical, scientific and intellectual, human) to identify and solve the environmental problems of the region; 3) coordination and integration of efforts and resources of all sectors of society (state, private-commercial, public) to achieve the goals of sustainable (balanced) development of the region.

In the context of a management-oriented approach to the formation and implementation of the regional environmental development policy, the practice of environmental management has become widespread. The 
most complete interpretation of environmental management is given in the international standard ISO 14000:

The environmental management system is a part of the general management system, which includes the organizational structure, planning of activities, distribution of responsibility, practical work, as well as procedures, processes and resources for development, implementation, assessment achieved results of implementation and improvement of environmental policy, goals and objectives (International Standard, 2004).

The environmental management system is a part of the overall management system, which includes the organizational structure, planning of activities, distribution of responsibilities, practical work, as well as procedures, processes and resources for the development, implementation, assessment of the achieved results of implementation and improvement of environmental policy, goals and objectives.

The basis of environmental management as an environmentalcentered management system are environmental standards: international (ISO 1400o) and national, state level (state standards and specifications (State Standard of Ukraine), and the main tools are environmental audit, environmental monitoring, environmental regulation, environmental certification and labeling. In the formation and implementation of the environmental development policy of the region, the managementoriented approach will contribute to: 1) the creation of an organizational management structure based on the principles of economic regulation; 2) strengthening the corporate environmental responsibility of economic entities in the region; 3) development of a "green" regional economy.

\section{Analysis of the possibilities of practice-oriented approaches to the formation and implementation of the policy of ecological development of the regions}

To determine the management potential of the selected practiceoriented approaches in the management of the ecological development of the regions, the sociological method of an expert survey was applied among the subjects of public administration in the field of environmental protection of Zaporizhzhia region (January 2020, $n=200$ ). Survey sampling - 200 experts, among them: 50 - government officials (representatives of government bodies in the field of environmental protection), 50 - public activists in the field of environmental protection, 50 - representatives of large business in the region, 50 - environmental scientists. 
Hryhorii Bukanov, Svitlana Skakovska, Viktor Kulbaka, Olena Sytnichenko y Olesia Kulbaka 208 Training and implementation of the environmental, economic, and legal development policy of the regions: main practice-oriented approaches

Figure 1 shows the results of an expert survey to identify the most effective mechanisms and tools for the formation and implementation of the regional environmental development policy. To this end, the experts were asked to identify five answer options (mechanisms and tools), which, in their opinion, have significant managerial, resource and realistic potential in the formation and implementation of the regional environmental development policy.

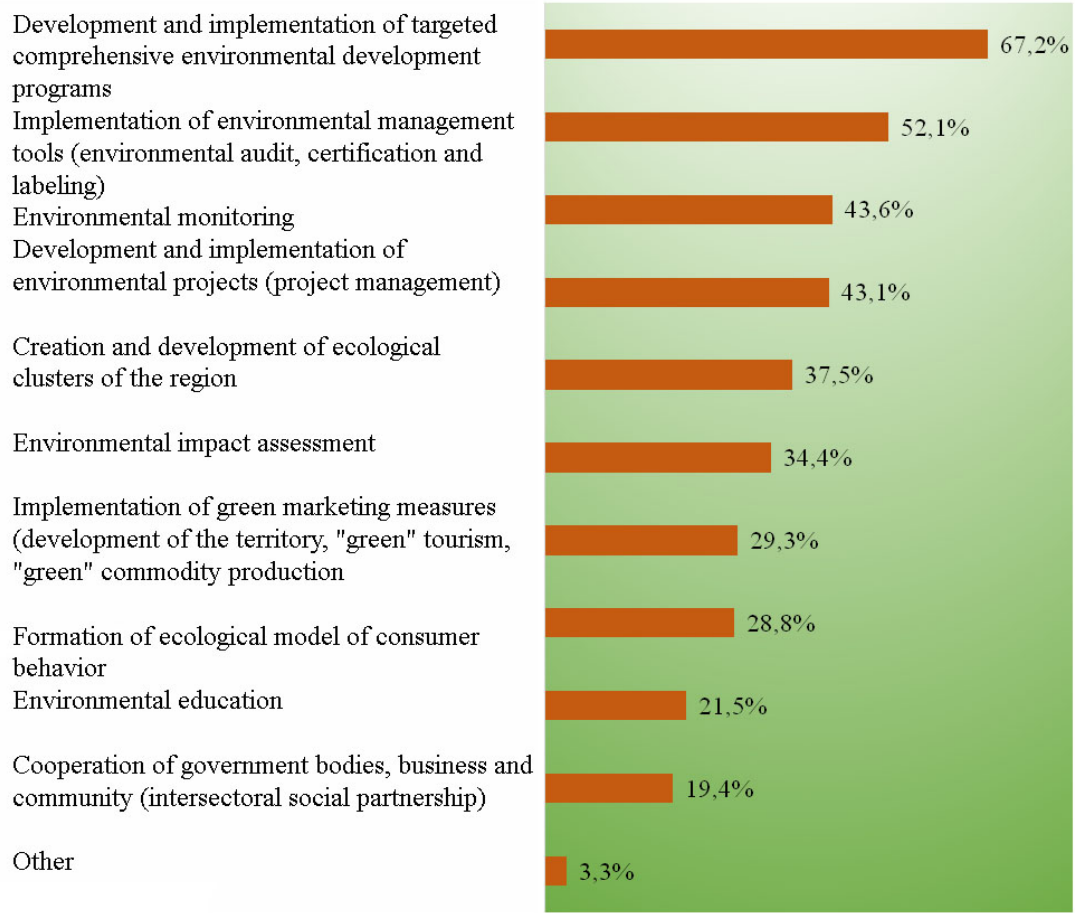

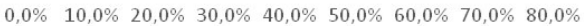

\section{Fig. 1. Assessment of the potential of mechanisms and tools for the formation and implementation of the regional environmental development policy (up to five answer options could be chosen) (Own elaboration).}

The proposed mechanisms and tools correspond to the main practiceoriented approaches in managing the ecological development of the region: in the context of the program-targeted approach - the development and 
implementation of targeted integrated programs; cluster approach - the creation and development of environmental clusters in the region; projectoriented approach - the development and implementation of environmental projects, "green" marketing, social partnership; management-oriented approach - the application of environmental management tools.

According to the results obtained, traditional approaches to environmental management in the region have the highest indicator, namely, the development and implementation of targeted comprehensive programs for the social and ecological and economic development of the region. Environmental management tools have received a significant percentage of the potential opportunities. Of great importance is the implementation of environmental projects to enhance cooperation between regional authorities in the field of environmental protection, business structures (especially large polluting enterprises) and environmental public organizations.

Using the tools of statistical analysis of SPSS 14.0 of the frequency distribution of the obtained results, the average values (from 1 to 5 points) were determined to assess the potential of cluster, program-target, project-oriented and management-oriented approaches in the formation and implementation of environmental development policy in general. throughout the sample and depending on the professional status of the experts (Fig. 2).

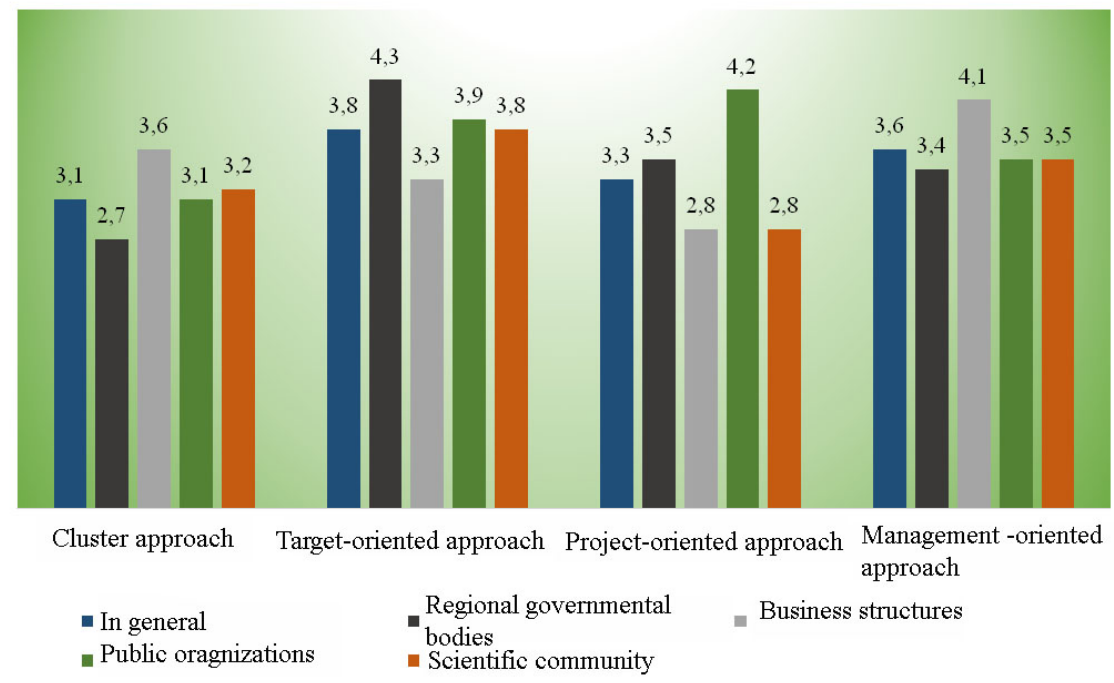

Fig. 2. Assessment of the potential of practice-oriented approaches in managing the environmental development of the region (Own elaboration). 
Hryhorii Bukanov, Svitlana Skakovska, Viktor Kulbaka, Olena Sytnichenko y Olesia Kulbaka 210

Training and implementation of the environmental, economic, and legal development policy of the regions: main practice-oriented approaches

\section{Directions of public administration optimization in the field of ecological development of the regions}

Based on the results of theoretical and empirical analysis, it is possible to determine the main directions for improving the management system in the field of environmental development at the regional level. In this direction, the modern scientists and researchers work quite fruitfully. For example, G.Shumska names the following as the priority tasks of regional authorities in the implementation of the regional environmental development policy (Shumska, 2017): the identification of regional environmental problems; the designation of potential sources of financing for the ecological sphere of the region; the creation of an environmental infrastructure that will help to attract business structures, in particular cluster ones, to solve environmental problems; the control over financing and implementation of environmentally oriented regional investment programs and projects; the development of new organizational and economic mechanisms for environmental management both at the regional level and at the level of a specific enterprise.

O.Kolienov proposed the following directions for improving the mechanism for the formation and implementation of regional environmental policy (Kolienov, 2017): the development of public-private partnerships and environmental responsibility of business and society; the development of a system of economic incentives in the field of environmental protection; the formation of a unified regional system of environmental monitoring; the urgent reform of the public administration system in the field of environmental protection towards the transition to integrated state-public administration; strengthening control and responsibility on the part of the state and the public; the adaptation of state environmental policy to European standards and the best world practices; the gradual transition from prescriptive public administration to democratic state and public administration in the environmental sphere.

Fig. 3 presents the results of an expert survey on the factors of increasing the efficiency of public administration in the field of environmental development of the regions. 
Increasing of budget funding

Improvement and adaptation of national environmental legislation with $\mathrm{EU}$ legislation Modernization of the system of state and public administration in the field of environmental protection

Formation and development of the environmenta management system at all levels of management Introduction and dissemination of economic incentive instruments

Creation a favorable "green" investment climate Creation and development of a network of environmental clusters

Increasing the level of information and communication interaction with the population

Strengthening international cooperation

Creation of an institutional structure of social partnership in the region

Creation of an institute for the management of environmental projects ("project office")

Development of an electronic environmental regional governance

Other

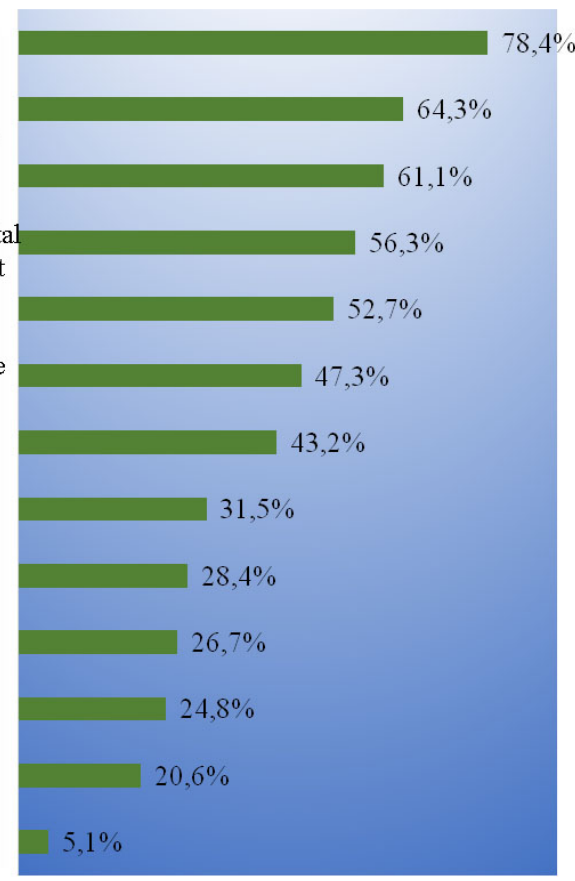

$0,0 \% 10,0 \% 20,0 \% 30,0 \% 40,0 \% 50,0 \% 60,0 \% 70,0 \% 80,0 \% 90,0 \%$

Fig. 3. Factors of increasing the efficiency of public administration in the field of environmental development of the region (up to five answer options could be chosen) (Own elaboration).

Thus, it is possible to determine the ways to optimize public administration in the field of formation and implementation of the policy of ecological development of the regions according to the selected practiceoriented approaches:

- on the cluster approach:

1) the development of a regulatory framework for the creation and functioning of environmental clusters.

2) the information support for promoting clustering of regional development of Ukraine among economic entities, regional and local government bodies and environmental public organizations.

3) strengthening economic incentives for the development of environmental clusters: 
Hryhorii Bukanov, Svitlana Skakovska, Viktor Kulbaka, Olena Sytnichenko y Olesia Kulbaka

on the program-target approach:

1) the inclusion and strengthening of the ecological block of programs and strategies for social and economic and sustainable (balanced) development of regions with a specific plan of action and measures and the definition of expected results and deadlines.

2) strengthening the functional powers of regional and local authorities in the field of environmental protection.

3) the involvement of all sectors of society (state and regional authorities, business structures, public organizations, scientific and educational institutions, community in general) in the development and implementation of comprehensive targeted programs for the ecological development of the region based on the principles of intersectoral social partnership.

on the project-oriented approach:

1) the introduction of project management tools into the environmental management system (project cycle management, project management of organizational development of state bodies and organizations, project office management).

2) the dissemination of benchmarking technology in the development of projects in the field of environmental protection.

3) the inclusion of tools and mechanisms of environmental marketing and marketing of sustainable (balanced) development of territories into the system of project-oriented management; 4) the development and implementation of investment projects for the development of a "green" economy.

On the management-oriented approach:

1) the introduction and strengthening at the regional level of environmental management tools (environmental audit, environmental monitoring, strategic environmental assessment, environmental certification, environmental labeling).

2) the legislative consolidation and regulation of economic mechanisms and tools for the implementation of regional environmental policy.

3) the introduction and dissemination of electronic environmental management tools. 


\section{Conclusions}

Based on the results of theoretical and empirical analysis, we made the following conclusions.

1. The formation and implementation of environmental development policy can be carried out both in the context of traditional and wellestablished practice-oriented management approaches (targetoriented and project-oriented) and modern approaches based on the principles of sustainable development (cluster and managementoriented), and their complex application will contribute to the development of the region in social, economic and environmental aspects.

2. The most managerial and resource potential, according to the results of the expert survey, is possessed by target-oriented (as traditional, customary) and management-oriented approaches in managing the ecological development of the region.

3. Among the leading directions of optimization of public administration in the area of environmental development of the region, the following are identified: 1) the improvement of environmental legislation and regulatory policy in the area of allocation of budgetary financing for environmental protection in the regions; 2) the creating conditions for the development of regional environmental clusters and the introduction of a regional environmental management system; 3) the spread of state-private-public partnership in the management of the ecological development of the region.

\section{Bibliographic References}

ANDRIIENKO, M.V., SHAKO, V.S. 2017. Mechanisms for the implementation of state environmental policy at the regional level. Investments: Practice and Experience, No. 18, 47-53.

CHEMERYS, A. 2012. Development and management of projects in the public sphere: the European dimension for Ukraine. K: LLC "Sofia-A". Ukraine, Kiev.

DEHTIAROVA, I.B. 2010. "Environmentally oriented clusters as a form of effective development of ecological and economic systems" In: Mechanism of regulation of the economy. No. 1, pp. 47-52.

INTERNACIONAL ORGANIZATION FOR STANDARDIZATION (ISO). 2004. Environmental management systems - Requirements with guidance 
Hryhorii Bukanov, Svitlana Skakovska, Viktor Kulbaka, Olena Sytnichenko y Olesia Kulbaka the regions: main practice-oriented approaches

for use. Available online. Is: https://www.iso.org/standard/31807.html. Consultation date: $15 / 11 / 2019$.

KOLIENOV, O.M. 2017. "Priorities for the implementation and assessment of state policy in the field of environmental safety" In: Bulletin of the National University of Civil Protection of Ukraine. No. 2, pp. 127-133.

KOVAL, Viktor; MIKHNO, Inesa. 2019. "Ecological sustainability preservation of national economy by waste management methods" In: Economics. Ecology. Socium. Vol. 3, No. 2, pp. 30-40.

KOZACHENKO, T.P. 2018. "Public administration based on project management: a modern perspective" In: State and Regions. Vol. 2, No. 62, pp. 50-55 [in Ukrainian].

PAKULINA, A.A; BELICHENKO, A.O; PAKULINA, H.S. 2019. "Regional programs as a means of linking economic, social and environmental development goals of the territory. Economy and management of the national economy" In: Market infrastructure. No. 34, pp. 58-64.

POLLITT, Christopher; BOUCKAERT, Geert. 2004. Public Management Reform: A Comparative Analysis. Oxford University Press. Oxford, United Kingdom.

POPOVA, Olga L; KOVAL, Viktor V; MIKHNO, Inesa S; TARASOV, Igor V; ASAULENKO, Natalya V; FILIPISHYNA, Liliya M. 2020. "Assessments of national tourism development in terms of sustainability and inclusiveness" In: Journal of Geology, Geography and Geoecology. Vol. 29, No. 2, pp. 377-386.

SHUMSKA, H.M. 2017. "Theoretical and methodological aspects of the implementation of regional and environmental policy" In: Economy and Society. No. 12, pp. 432-439.

TAMOSIUNIENE, Rima; DEMIANCHUK, Maryna; KOVAL, Viktor. 2019. "State Regulation of Bankruptcy Relations in the National Economy" In: Economics. Ecology. Socium. Vol. 3, No. 4, pp. 19-27.

TOMAREVA-PATLAKHOVA, V.V. 2017. "Identification of the influence of the determinants of an unstable environment on the implementation of state regional policy in the context of global challenges" In: Priazovskyi economic bulletin. Development of productive forces and regional economics. Vol. 01, No. 01, pp. 70-79.

YANKOVYI, Oleksandr; KOVAL, Viktor; TROKHYMETS, Olena; KARPENKO, Maryna; MATSKEVICH, Yuliia. 2020. "Economic assessment of investment on the basis of production functions" In: Turismo: Estudos \& Práticas. Available online. In: http://natal.uern.br/periodicos/index. $\mathrm{php} / \mathrm{RTEP} /$ article/view/1310. Consultation date: 12/03/2020. 
Vol.38 NEspecial

Esta revista fue editada en formato digital y publicada en diciembre de 2020, por el Fondo Editorial Serbiluz, Universidad del Zulia. Maracaibo-Venezuela 